\title{
Review of the Survey's activities in 1978
}

\section{K. Ellitsgaard-Rasmussen}

Director

The main field activity of the Survey in 1978 was a study of the geology of North Greenland (fig. 1). This was the first summer of a three year project which aims at a geological synthesis of the whole region together with the compilation of two 1:500 000 geological maps. Significant additions to the geological knowledge of the area included the discovery of an extensive Proterozoic basalt province, an extension of the known distribution of the late Proterozoic to Silurian strata, and of the late Palaeozoic to Tertiary Mesozoic sequences of the Wandel Sea Basin. The field work has been undertaken in cooperation with the Geodetic Institute, establishing a set of ground central points for the preparation of topographic maps of northern Greenland. These maps will be based on a new set of aerial photographs which were taken during the summer. The Danish Air Force using a Hercules aircraft flew in the group of 32 geologists and surveyors and their equipment to Station Nord. Geological studies and surveying went according to plan, in spite of more snow cover than usual in most of Peary Land.

The Survey's field activity elsewhere has been in the form of several smaller projects, some of them continuing, some completed, with one new project being started.

In North-West Greenland geological investigations continued in the Thule and Melville Bugt areas on the northern part of the 1:500 000 sheet 4 (fig. 2) and north of this in the eastern part of the Thule area. In central West Greenland field work was completed on the Archaean and early Proterozoic rocks between Sukkertoppen and Søndre Strømfjord on the 1:500 000 sheet 2 and compilation of the sheet is now well advanced. Sheet 2 completes the set of three sheets at this scale that will cover the west coast of Greenland from the extreme south as far north as latitude $71^{\circ} \mathrm{N}$, north of Nûgssuaq.

As part of the 1:500 000 mapping projects work continued during the year in South-East and East Greenland. In South-East Greenland a party of five geologists continued work on the Archaean, Proterozoic and Tertiary rocks between Kangerdlugssuaq and Angmagssalik from the M/V Tycho Brahe. Further north a party continued investigations on the basalts of the Blosseville Kyst.

The 1:100 000 mapping of the Agto sheet was completed during the year. It has been carried out by a team from the University of Aarhus. The mapping of the 1:100 000 sheet around Godthåb was in its final stage during the summer.

A new mapping project was started by a group from Copenhagen University, 


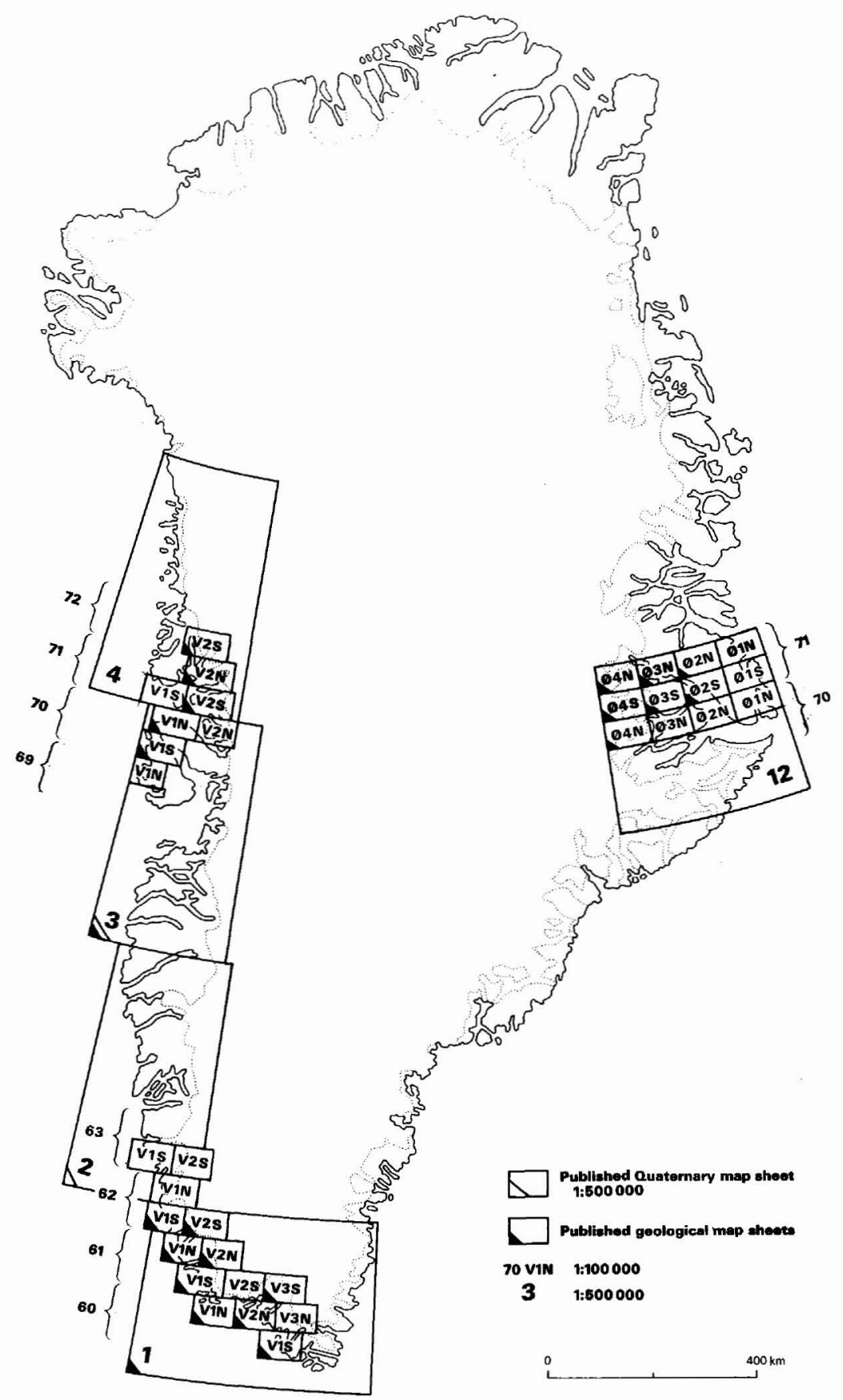

Fig. 2. Map sheets published and in preparation by the Survey (see inside rear cover). 
consisting of a lecturer and three senior students with assistants. The area which is covered by the 1:100 000 Agpat sheet $(70 \mathrm{~V} .2 \mathrm{~N})$ consists of Archaean and Proterozoic rocks situated to the south of the Mârmorilik sheet, and includes the extension of the Proterozoic marbles of the Mârmorilik Formation that at Sorte Engel contain lead and zinc mineralization. The project is expected to extend over a three year period.

Special projects include further work on the Tertiary basalts along Disko Fjord and the surrounding area where they locally contain native iron. The field work was supported jointly by the Danish Natural Science Research Council (SNF) and the Survey. On the southern part of the Ilimaussaq intrusion in South Greenland detailed mapping work was continued and in the Narssaq area hydrological data were collected as in previous years. In East Greenland three parties worked on stratigraphic correlation problems north and south of Mesters Vig.

The magnetic and radiometric surveys in central West Greenland continued with investigation of anomalies identified during airborne programmes of 1975 and 1976. Both groups were based on Søndre Strømfjord and field parties were supported from there.

In recent years the Survey has operated with projects that have been financed largely by outside sources, a method of financing likely to continue for the foreseeable future. Projects are of one to two years in length with part of the funding coming from the Energy Agency of the Ministry of Commerce, and part from the European Economic Communities (EEC). In 1978 there were four such projects. Project WESTMAR comprised shallow geophysical surveying on the continental shelf off West Greenland. This work was carried out from the M/V Dana and preliminary results are now available as GGU Report No. 87. Another project partly financed by the EEC, was a continuation of the study of the hydrological balance over the catchment area in Johan Dahl Land in South Greenland. The third project, EASTMAR, comprises an aeromagnetic investigation of the East Greenland shelf area based on existing data, with acquisition of new data in areas not yet covered. At the end of the year a contract was signed with Aero Service Division, Houston, for the airborne operations to be carried out in 1979. The Kvanefjeld project continued during 1978 with the detailed study of the bore core material collected in the first stage of the project.

The Survey organised an international excursion financed by a NATO Scientific Research grant and by national research organisations for a study of early Archaean rocks. A party of 14 participants of which 3 were from GGU spent up to 5 weeks in the Godthåbsfjord and Isukasia areas. The Survey also organised an excursion of 15 uranium geologists from OECD member countries to the Ilimaussaq intrusion in South Greenland.

The Survey continued its inspection function for the Ministry for Greenland in connection with the lead-zinc mining at Sorte Engel and cooperates with the Cana- 
dian environmental authority with exchange of data. One party participated in an environmental study in the area of the uranium deposit in South Greenland. The negative results of petroleum exploration offshore West Greenland in earlier years led to an almost total cessation of work in the concession areas in 1978. The Survey advised the Ministry for Greenland on the consequences of this in the light of the work commitments attached to the concessions.

One map sheet was published during the year: the Quaternary sheet 2 at 1:500 000 (Frederikshåbs Isblink - Søndre Strømfjord). Several sheets at 1:100 000 are at various stages of preparation in the drawing office. Other publications issued by the Survey during the year included 5 Bulletins, 2 Reports and 7 Miscellaneous Papers, together with the annual Recipientundersøgelse, Ag-

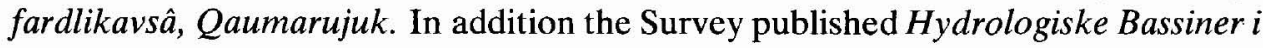
Vestgrønland, a work delineating the natural hydrological catchment areas and their water potential in West Greenland.

During the year three short-term contract scientific personnel were attached to GGU, all the contracts being financed jointly by the EEC and the Ministry of Commerce. 